Марија Љ. Ивановић*

Библиотека града Београда

Завичајно одељење https://doi.org/10.18485/analiff.2020.32.1.6

821.163.41.09-3:398

Originalni naučni rad

Primljen: 23.03.2020.

Prihvaćen: 24.05.2020.

\title{
ПРЕВОЪЕЊЕ СРПСКЕ НАРОДНЕ (ЕПСКЕ) ПЕСМЕ У СРПСКУ ИСТОРИЈСКУ ДРАМУ: МНОГОСТРУКОСТ ЗНАЧЕЊА У ДРАМСКОМ СТВАРАЛАШТВУ АТАНАСИЈА НИКОЛИЋА
}

У раду се сагледава вишеструки значај српске историјске драме у књижевном стваралаштву Атанасија Николића спрам важности очувања знања из народне историје и традиције. Настала транспозицијом српских народних епских песама у драме, Николићева дела, одржавајући развојни континуитет народне културе - својим аутентични изразом, осавремењивала су народну традицију те утицала на одржање и обнову српске културе у устаничком XIX веку. Циљ рада је да истакне многоструки значај историјских драмских остварења, и уочи њена општа дејства на тамошњи српски народ. Разматран је и проблем релативизације њихових вредности. Под методолошком концепцијом која се ослања на Шлегелово виђење позоришта по коме оно може да има „особиту дражест за све векове, родове и стања људи“, очекивани резултати тичу се досега могућности народног духа (уденутих у историјску драму) по развој културе, за коју нам се чини да што је дубља - изворнија, више добија на значењу и значају, с тенденцијом да постане универзална, архетипска.

Кључне речи: култура, традиција, епос, народно стваралаштво, „сопствено“, српска историјска драма, Атанасије Николић

\section{1. УВОД}

„Уметност се брани тиме што пре или после превладава једностране калупе у које је уливају, показујући да је, као живот сам, несводљива на један назор или једну доктрину; време је на њеној страни““ (Џаџић, 1975:127).

Овим истраживањем даје се осврт на поједине видове историјског, друштвеног, просветног, уметничког и пре свега хуманистичког значаја књижевног стваралаштва Атанасија Николића, српске

* 3мај Јовина1, 11000 Београд. marijamilic011@gmail.com. 
историјске драме те уопште народне историје и традиције. Како различите епохе немају заједничке ослонце, тумачена област сагледавана је у односу на неодвојиву условљеност захтевима времена и простора момента када је књижевно-театарско дело стварано.

Епска остварења ${ }^{1}$ преведена у драмска, имајући учешћа у развоју и обнови културне историје Срба у околностима вишевековне стеге српског народа под турском окупацијом, разматрана су и кроз могућности народног духа које као специфичан реалитет бивствују у многим културама. Култура је прихваћена као одраз или „резултат вековног и заједничког прегнућа“, како је врсни познавалац културе и уметности Милан Кашанин говорио, па у сваком добу, „у сваком народу, религији, држави, она добија нарочито своју боју, изузетан сјај и прелив, предодређен дах, те се нама чак данас чини, да један народ - у историји, у толико више вреди уколико је у духовном твораштву био свестранији и дубљи, широко човечан остајући, доступан, обилан“ (Кашанин, 1930:[93]).

\section{2. О ВАЖНОСТИ ОЧУВАҢА ЗНАЫА ИЗ НАРОДНЕ ИСТОРИЈЕ И ТРАДИЦИЈЕ: СРПСКЕ НАРОДНЕ ПЕСМЕ}

Разматрања о важности очувања знања из народне историје или традиције датирају још од античке грчке. Препричавајући разговор Сократа и Перикла, Ксенофонт је истакао Сократово виђење на ту тему, који тврди, да ако би се проширила та знања (у случају српске културе би то било интересовање за славну прошлост српског народа), „уместо малодушности, могло би се опет разбудити старо срце јуначко“ (Анастасијевић, 1929:226). Наглашавајући друштвени и хуманистички значај народне традиције, Ксенофонт истиче и следећу Сократову мисао која налаже „да ако се код народа оживе успомене на славна јуначка дела њихових предака, да она имају моћ и да духовно

1 За разлику од ширег значења епоса који обухвата читаву наративну књижевност, епос у ужем, изворном значењу (који се у раду усваја) односи се на „наративна дела у стиху која се баве великим и озбиљним темама, на дела која певају о херојима, о полубожанским или божанским лицима од којих зависи судбина племана народа или људског рода те у чијем начину излагања преовлађује подигнут, узвишен и свечан стил” (Деретић, 2000:14). 
окрепљују и одушевљавају за нове подвиге, па је стога ту с правом Сократу преписана „ни мање ни више него мисао о могућности препорођаја клонулог народа помоћу његове властите народне историје“ (1929:227).

Српске народне (епске) песме једна су од најлепших завештања српској култури или народној историји, која пак не може да се разуме без њих. Као њен саставни и нераскидиви део, српске народне песме обдарене моћном духовном снагом, помогле су српском народу обнављање државности у XIX веку. Јаков Игњатовић говорећи за народне песме за које се ретко зна од кога су, истакао је да оне јесу ваљане зато што су при свом стварању „процеђене кроз срце народно, па остаје сам чист сок. Ако ко шта рђаво скроји“, додаје, „то мора проћи кроз пресуду народног срца и уха, па ако врећа - одбаци се, или за дуго не живи“ (Игњатовић, 1874: 35).

Период вишевековног турског господарења Србијом - доба српске велике трагедије, уденут је у српску народну поезију која је зато пуна и неизмериво дубоке туге. Потпуности српске народне (епске) песме доприноси, с друге стране, и постојаност осећања и жеље ка великој борби за ослобођење, те је присуством и призора обележених „оптимизмом који подстичу на прегалаштво, на рвање са тешкоћама, на смеле подухвате“ (Ђурић, 1958: 11-12), у српској култури, остварен народни израз који као ,поклич за борбу против насиља, ропства, нечовештва“ (1958:12), добија своје значење.

Прожете садржајем о људским врлинама, јуначности и осећајности, српске народне песме образовале су млади нараштај који је у њих уденуо своје колективно искуство и доживљај света или силу, према Штуру обликовану као „,пакт и врх свију вештина“33 (Штур, 1857:22). У таквом исказивању и усвајању историјско-легендарне прошлости српског народа, оне осим што су утицале на поучавање српског народа, уједно су имале утицаја и на формирање моралне снаге ума код Срба. Друштвено уједињујуће, као уметничка дела и као друштвени организми, уздижући културну и политичку самос-

2 „Поезија је пакт и врх свију вештина, и најпристојнији, најразумнији и најчовечнији начин за народ, да искаже оно, што мисли да је лепо и високо; а народ, који се на тај начин и у потпуно људском духу исказује, мора имати у срцу и души својој највише тога високога жара“ (Штур, 1857:22). 
вест српског народа, помогле су борбу за национално ослобођење и независност.

Тако прихваћен значај српске народне песме, препознат је пре свега у значају традиције путем које је могуће остварити исконску потрагу за индивидуалним и колективним иденититетом. Снагом оригиналног и аутентичног твораштва, народни епос својим трајним и континуираним „знчењима одређених опредељења и идеја”, омогућио је српској култури (,вековном и заједничком прегнућу колектива") сталност и постојаност...

„...Сваки народ има изнад себе такво небо појмова математички размештених и, на захтевање истине, схвата да убудуће сваког појмовног бога не тражи другде него у његовој сфери“, говорио је Ниче. Тумачење те његове тврдње изнео је Барт следећом, по којој смо „сви захваћени истином језика, то јест његовом регионалношћу, увучени у страшно гложење које управља њиховим суседством. Јер, сваки тип говорења (свака фикција) бије битку за хегемонијом; ако има моћи за себе, распростире се широм текућег и свакодневног друштвеног живота, постаје доха, природа““ (Барт, 2011:117).

Српске народне песме су својом животном филозофијом дозволиле српском народу, да кроз лично и национално, досегну и оно светско (универзално) и пре свега опште људско. Са рефлексијом којом се човек „бори за своју потпуност, за свој људски лик, за своју извесност, најзад и за своју слободу“ (Џаџић, 1975:228), оне су продрле у српски народ, дајући потоњим „исповедачима“ више психолошких могућности да се кроз сопствено „целовитије и ефикасније изразе а непосредније и сугестивније делујући на свест и машту публике“ (Финци, II, 1961:10-11).

\section{3. РАЗВОЈНИ ПУТ СРПСКЕ ИСТОРИЈСКЕ ДРАМЕ}

За разлику од епске поезије (од грчке речи ёлбৎ - слово, реч, стих, од ёлஸ் -приповедати) у којој се описују или исповедају (испевају) дела „позоришних“ лица, у драматици иста лица сама раде и говоре.

Српске народне јуначке или епске песме које су певане уз гусле, обично су исповедали (изводили) слепи људи око којих се окупљао народ, да би заносно слушао чинове својих јунака и уопште о сопственој народној историји. У периоду када су се гусле све мање чуле 
по скуповима или сајмовима, крај пијаца или на саборима код манастира Срба, као ново место окупљања где су се та знања и вредности која чине традицију транспоновала, јавило се позориште.

Имајући у виду доба бесомучног турског зулума према праву интегритета и праву слободног изражавања Срба, постојано интересовање за српску драмску историјско-легендарну тематику које је бивствовало као одговор на захтеве времена и простора не чуди. Пријемчивост српског народа и приврженост таквом садржају, доприносили су да стари конвенционални облици у којима је живела српска народна историја и њен етички кодекс, добивају сагласно духу времена нови живот - с истим елементима митског и историјског погледа на свет. Познато је да (је тамошњи) српски народ српску историју доживљава(о) управо као трагедију о чему је писала Марта Фрајнд када говорећи о специфичностима историјских драма, конкретно драмском спеву Симе Милутиновића Сарајлије и Петра Петровића Његоша, наводи „отворену структуру, засновану на јединству историјске или епске приче, на унутрашњем јединству појединачних сцена, те на свеобухватном јединству виђења света, историје, епа и националне слободе“ (Фрајнд, 1993:249).

„За публику је свака озбиљна драма, то јест драма са историјском тематиком, била трагедија чије је извођење просечног српског гледаоца привлачило темом из српске историје која је у оквирима драмске обраде била прожета мелодрамским елементима, пре свих мотивима љубави и победе добра над злом, костимираним ликовима и извесном сценском спектакуларношћу“ (Несторовић, 2016:282-283). Из жеље да се удахне нови живот српским народним и јуначким песмама, да се оживе оне карактерне особине српског народа које су биле потискиване из народне свести те да се одржи континуитет са средњовековном држвом, настајале су српске историјске драме, које су као врло тражене па и најразвијеније у жанровском систему сценског приказивања постајале свеприсутна појава друштвеног и државног живота српског народа.

Традиционално конципирање театра као националне потребе, као институције којом је могуће пробуђивати дух народности, за српско позориште видно је карактеристично највише током XIX века. У времену оформљавања првог државног сталног позоришта у Београду - „Театра на Ђумруку“ чији је оснивач Атанасије Николић, чак се у 
Марија Љ. Ивановић

„Новинама сербским“ упућивао позив „управитељства“ позоришта да се пише управо таква књижевна врста која обрађује народну историју, народни карактер и обичаје. „Нацонално позориште тражи националну драму, а она је одређена историзмом“ (Несторовић, 2016:41). Српска историјска драма настала из потребе формирања националног позоришта али и пре свега потребе народа да кроз властито искуство и могућности искаже оно што чини колективну националну свест једног народа, остала је природно доминантан жанр на српској сцени све до Првог светског рата.

Својим (трајним) знчењем одређених опредељења и идеја (животном филозофијом), српске историјске драме осведочавале су постојаност једне духовне струје код Срба. Обликоване у новом руху али тог једног одређеног типа изражавања и доживљаја света, српска историјска драма успевала је да досегне онај „обавезни спој прошлости и садашњости који је карактеристичан за жанр историјске драме, оно спајање и поистовећивање ,јуче“ и „данас“ (...) на којој је ,јуче“ само историјски костим (био) за „данас“ (Јеротић, 1998:156).

Перципирањем позоришта као активног чиниоца у друштву народа, које не представља место које само треба да забави, већ и место где се врши ,потрага за идентитетом или начином самопотврђивања“ (Волк, 1992:13), подстицало се дакле буђење народне самосвести. Утичући на стварање свести народа о себи, о сопственој култури и њеном значењу, заслуге аутентичних српских историјских драма утолико су веће биле, што су оне образовале и васпитавале народ. Јован Стерија Поповић је неретко износио да је “театар лек за болести моралне“. Стваране у духу просветитељско-родољубивих тежњи, оригиналне српске историјске драме представљале су синониме највиших вредности српског драмског стваралаштва - што се временом, нажалост, прилично изменило.

Очигледна свеприхваћеност и доминација српске историјске драме током свих година XIX века, у наредном периоду другачијих политичко-социјалних и догматских уверења, постепено је слабила, да би се најпосле, заједно са епском поезијом, угасила. ${ }^{3}$ Такве окол-

3 Како у првим деценијама XX века још није било радија и телевизије, Народно позориште дотад је било једано од главних културних светионика Београда.. 
ности које су постепено налагале нови тренд, отварајући пут новим делима другачијег тематско-мотивског профила који је више придавао значај психологизирању него теми, као и ликовима уместо самој причи, утицале су на постепено формирање негативног става о вредностима самих историјских драма.

„Са променом поетичких парадигми у књижевности које су од класицизма и његове етичности изражене у морализму и дидактизму, водиле ка романтизму и његовој естетичности, артизму, мењао се доживљај драме као књижевног рода“ (Несторовић, 2016:58). Приче о борби добра и зла које карактеришу класицистички поглед на свет, бивале су превладаване предромантичарским и романтичарским ${ }^{4}$ увидом у „структуирање“ радње у којима се тежиште с историјсколегендарне прошлости српског народа - колектива, премештало на унутарњу борбу јунака - појединца. Тако је могућност досезања „,трагичког потенцијала“" ствараног развојем унутрашњег сукоба романтичарског јунака, створило и „отклон од великих тема ране српске драматике“" (2016:296).

Поступком „карактеризације ликова“ којим се битно мењала драматуршка обрада тема у којима би у почетку „мали човек племенитих осећања представљао противтежу драмским причама о судбинама узвишених ликова национално-легендарне историјске повеснице“ (2016:344), а судбина појединаца симболично осликавала судбину народа, отварао се продор реалистичке поетике у српску књижевност. Иако су у том првом периоду, укрштајем старих конвенционалних облика с романтичарском изражајношћу стварана дела највећих вредности каква су драме Лазе Костића, Ђуре Јакшића и других, постепеним па касније све већим увођењем свакодневице најпре паланачког а затим градског живота, полако се подстицало и тривилизовање прошлости. Продирањем капитализма одн. упливом мотива новца али и технике као тековина модерности, вршила се и специфична промена друштва. ${ }^{5}$ Раскид с традицијама у име разума и револуције поисто-

4 У томе продор нових аспеката подразумева и ,романтичарску одушевљеност мистичним и егзотичним, елементе модерности....“

5 Уплив најпре Марксовог капитала, па Дарвинове теорије а најпосле Фројдове психоанализе перцептуира се као прекретнички у погледу револуционарних струја које су захватале друшто XVIII и XIX века. 
Марија Љ. Ивановић

већивао се претежно с „модерним друштвом“, чиме се губио све више континуитет са ранијим генерацијама, а приклањајући се данас „култури имага“ (Лаш, 1986) и „посмодернистичком захтеву за укидањем уметности и њеним изједначавањем са стварношћу“, о чему је писао Кристофер Лаш. ${ }^{6}$

Као резулт једног таквог глобалног процеса, српска историјска драма XIX века, кроз потоњи XX, системски је остала занемарена. С тим у вези умесно је дотаћи и покренути и питање о важности одређивања ваљаног културног програма или репертоара - душе сваког театра, чија је политика према Финцију важна за „карактер и физиономију једног позоришта - за његову улогу у интелектуалном и моралном кретању друштва“ (Финци, 1961:10). Тај критичар позоришне уметности изрекао је важну опомену, по којој би репертоарска политика као одраз уметничке колективне одабраности оних дела која ће бити на програму једне позоришне куће, требало да има обавезу неговања и развијања националне културе! Пре свега „преиспитивањем репертоара, његових врлина и мана, смелих подвига и трагичних падова“, истиче Финци, „лако се могу оценити процеси напредовања или стагнације, правилне усмерености или погрешних тежњи и свих осталих видова театарске уметности“ (1961:10).

Будући да су изворне српске историјске драме стваране са задатком да оплемењују, поправљају, просвећују и освешћују српски народ, а имајући у виду и њихову велику делотворност, не изненађује исти подстрекивачки став још једног књижевног критичара Павла Поповића на ту тему, а који је истакла познавалац његовог дела Марта Фрајнд, којим вели да та драма с тога треба да се „популаруше, па ако треба и наметне примаоцима - српској публици (посебно ђацима)“ (Фрајнд, 1986:322). Знајући да су се у аутентичној српској драми славиле чисто моралне и човечје идеје ради друштвених, образовних и национално-културних циљева који се огледају у очувању идентитета српског народа и његове духовности, потреба за оваквим видом стварања у данашњем постмодерном добу укидања уметности намеће се као више него јасна.

6 Према Липовецком, за разлику од модерног доба које је било опседнуто производњом и револуцијом, постмодерно доба је опседнуто информисањем (Липовецки, 1987). 


\title{
4. ОСАВРЕМЕЊИВАЊЕ ТРАДИЦИЈЕ И МНОГОСТРУКИ ЗНАЧАЈ ДРАМСКОГ СТВАРАЛАШТВА АТАНАСИЈА НИКОЛИЋА
}

\author{
„Стваралаштвом, не само књижевним, и не само уметничким, \\ човек се бори за своју потпуност, за свој људски лик, за своју извесност, \\ најзад и за своју слободу. Песништво остварује живе и смеле пројекте \\ те борбе, и активистичког, не аутоматизованог човека. \\ Песништво је Анти-судбина“ (Џаџић, 1975:228).
}

Са жељом да се одржи континуитет са средњовековном државом, писци просветитељско-родољубивих тежњи XIX века, писали су српске историјске драме - праве ауторске индивидуалности драмске културе. Подстрек таквом току, где је потреба за враћањем на прошлост подједнако важна као и изгледи будућности, произлазио је из чврстог уверења српских културних прегалаца, да се излаз из кризе не проналази само у стварању новог духовног царства, већ и пре свега, у враћању на традиционали идеал.

Тако је гајећи љубав према прошлости и према српским народним песмама које је и сам сакупљао, у намери да им удели нови живот, Атанасије Николић писао српске историјске драме. Будећи веру и свест српског народа о непролазности његове културе, својим стваралоштвом, Николић је истицао некадашњи образац формиран кроз заједничко и вековно прегнуће српског народа и оживљавао оне карактерне особине које су биле потискиване у народној свести током векова.

Перципирајући шири контекст значаја његових драма које су као одраз реаговања на мукотрпну животну средину стваране, проматрање пре свега хуманистичке вредности његовог стваралаштва исто као и историјске, друштвене, уметничке те уопште културне, захтева један шири приступ процене, који произлази из укрштаја различитих метода научног рада а који може све да повеже. Излагањем значаја књижевног стваралаштва Атанасија Николића с више аспеката, добија се целовитија слика смисла и суштине његовог дела, а која у понеким случајевима када се говори о писцима из других епоха, може чак и више да каже о делу него оно само.

Најпре, намера писца да створи конкретно дело, узета је такође као фактор вредновања. „Историјска драма нужна је за стално под- 
Марија Љ. Ивановић

стицање племенитих осећања везаних за национално постојање, али и за градњу будућности на основним сазнањима о суштини националног бића” (Волк, 2009:41). Након што је у „Летопису Матице српске“ 1837. године изашао програмски чланак „Позориште, народње позориште, србско народње позориште“ у коме је разматрано Шлегелово виђење позоришта по коме оно има „особиту дражест за све векове, родове и стања људи, и било је увек најмилије увеселеније пуни духа народа“" (Павловић, 1837:21), отада је почео све више и све чешће да се истиче значај позоришта и драмске уметности по обликовање националног духа. У прилог истом ишла је и позната националноромантичарска теорија позоришне уметности Ф. Шилера, у то време актуелна, по којој:

„, gобра иоозорница има велики уйицај на gух начије... Само је йозорници моїуће gа сайласности нације изазове у највећем сиеиеену. Ако доживимо gа имамо национално йозо-

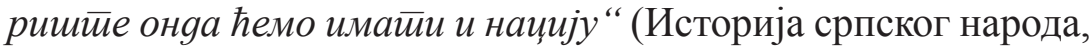
књ. V-2. 1981:397).

Познање да су изворне и аутентичне српске драме потребне позоришту, осим увида управитељства „Театра на Ђумруку“ који су вршили позиве при његовом оснивању, исто је било поимано и при прикупљању прилога за оснивање и подизање позоришних зграда у Новом Саду и Београду педесетих и шездесетих година XIX века. Тако је Јован Ђорђевић, будући оснивач Српског народног позоришта у Новом Саду, године 1852. у једном новинском запису понесено узвикнуо:

„Дајие нам gајйе - нове, изворне gраме! Та сваки вам

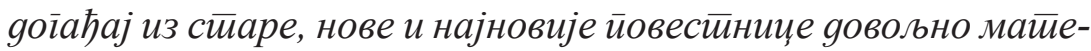
рије gаје какве ни Шексиичр није имао каgа је бесмриина своја gела иисао. Ено вам злайна и крвава времена Неманића, ено вам сјајно блеgа ейоха срйских десӣот̄а, ено вам јуначкоі інезяа Црне Горе, ено вам йужна ейоха срйской сужансиива и йурскої зулума, ено вам Црної Ђорђа и Мишарскоі йоља, ено вам србско-маиарскоі райа и србобранских беgема! Пииийе србске, ираве србске йозоришне иїре, йако вам Боїа! “ (1981:397). 
ПРЕВОЂЕЊЕ СРПСКЕ НАРОДНЕ (ЕПСКЕ) ПЕСМЕ У СРПСКУ ИСТОРИЈСКУ ...

Према казивањима појединих аутора, драмски писци писали су понекад српску историјску драму чак и када им се она није писала с обзиром на то да су веровали у њену битност. Тиме, значај српске историјске драме препознаје се најпре њеним уделом у формирању српског националног позоришта. Уздижућу културну и политичку самосвест српског народа, следстевно се утом препознаје и њихов значај у учешћу у борби за национално ослобођење и независност.

Дрматизацијом народних епских песама, Атанасије Николић је чувао темеље народног идентитета, подражавајући „национални етос”. Будући да се у тим драмама истицала човечност, емотивност, естетски садржај и мисаоност, те да се њима славило родољубље, праведност и поредак, значај је њихов утолико већи и што се исти („национални етос“) испољавао кроз узвишени категорички морал.

Говорећи о самој поетици Атанасија Николића, она је сва надахнута темама из националне (класичне) историје а с мотивима из традиције барока, ${ }^{7}$ и представљала је уједно и метафоричну и симболичну синтезу онога што уобличава српски поглед на свет (класицистичко-романтичарског доба). Својом суштином и значењем, сва је прожета моралистичком тенденцијом у духу просветитељства, и сентименталистичком тенденцијом где се превасходно истиче љубав према завичају. Писањем/извођењем нпр. драма о Краљрвићу Марку као „народно-карактеролошком идеалу“, Николић је кроз истицање човекове изузетности истицао важност борбе за правду и људске вредности. Значај величања идеала људског савршенства у делима Марка и других српских јунака, слично некадашњем величању гркчих богова, осим у јачању вере у сопствене снаге лежи и у моћи таквих личности да духовно уједињују и окрепљују сопствени народ. Као што су Аполон и други грчки богови били ујединитељи грчког народа, и српски јунаци о којима се најпре певало а потом изводило, будили су и развијали свест о српском идентитету, доприниосећи њиховом духовном јединству, јачајући и формирајући српски карактер, а чиме се морални значај његове акције додадно поткрепљује.

7 „Поетика барокног театра, за коју поједини истраживачи као нпр. Бенјамин, тврде да није поштовала аристотеловске принципе драмског устројства, на плану обликотворних поступака у однос константне напетости доводи управо вечност универзума и пропадљивост људске егзистенције“ (Несторовић, 2016:278-279). 
Марија Љ. Ивановић

Затим, драме Атанасија Николића и његових савременика, утицале су и на формирање грађанске јавности, односно формирање публике која критички почиње да резонује о култури, а чиме такође може да се искаже и њихов друштвени значај. Наиме, будући да је отварањем „Театра на Ђумруку“ грађанин могао први пут слободно да присуствује представама уколико купи улазницу, а што није био случај са првим државним али у суштини дворским - приватним позориштем у Крагујевцу - „Књажевско-сербским театаром“ (1833-1836) који је зачео Јоаким Вујић, утицало се на постепено формирање грађанске јавности. Окупљена из сфере приватних људи, публика успостављана у циљу просвећивања, јачањем своје критичарско-резонаторске моћи, све је више учествовала у побољшању тамошњих прилика. У прилог тој културној појави сведочи управо буна (отпор) грађанске јавности настале након противљења турског паше да се онемогући приказивање дела из српске историје која величају победе над османлијском војском. Заправо, по извођењу Николићеве драме „Краљевић Марко и Арапин“ којој се јавно одавала поштена хвала и за коју је било речи да је публика била „домородном ватром запаљена“, београдски паша се узнемирио. „Пештанско-Будимски Скоротеча“ од 19. јула 1842. год., имао је допис из Београда у коме се јавља, да је београдски паша озбиљно интервенисао због Краљевића Марка а и Милоша Обилића“ (Шумаревић, 1938:82). Пулс тамошњег јавног мњења уздрман немилим догађајима, дословно је изнет речима тамошње српске јавности:

„Познат̄о је gа је Паша забранио йакова gела ирреg-

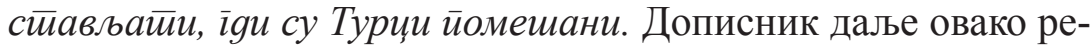
зонује: Сваки може лако забрањиваиии, ако їа gруіи слуша; но ми яржимо gа је ова стивар већа, неїо gа би је сам йаша решийи моїао!... Више би се, gакле, обшитој сиивари йомоїло, gа је Србско Правительство искало, gа се ова сиивар Пориии најире на размотиреније ирреяложи. Нашло би се, може битии, йамо љуяи којима ово не би йако зазорно било, као шиио се Паши чини. Иначе, ако овако йође, можемо дочекатии gа ће

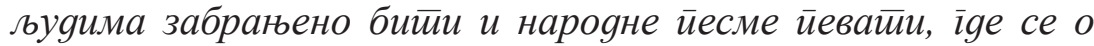
Туриима сиомен чини, йак онgа - јао и куку Србима и юиховом нароgносћу!" (Исто:82-83). 
Неприлике у аутономној али и даље вазалној кнежевини Србији, у земљи где је загарантована независна унутрашња управа с тзв. грађанским и људским правима али где и даље постоји обавеза да се плаћа царски харач и то у окружењу турског гарнизона с око 4.000 војника и 200 топова унутар градског бедема, походиле су српски народ. У овом листу јасно је осликано негодовање српске јавности постојећем стању те њено стремљење ка истинском праву на слободу изражавања, ка праву на неговање традиције за коју се вреди борити.

У прилог јачања резонаторске моћи тамошње грађанске јавности Шумаревић наводи још и једну незгоду која је стигла и са супротне стране, од саме српске публике. Наиме, Шумаревић тврди да у комадима који су се у то време изводили, „није смело бити турских испада, јер се одмах дизао револт у публици. Ако би се ту још појавио какав моменат, у коме би Турчин покушао да се приближи образу српске жене, онда се јављао протест против саме сцене на позорници..“"(Исто:84).

Распаљујући ватру љубави према старим српским јунацима, српске историјске драме Атанасија Николића, чиниле су и да се специфична форма тадашње “властите народне историје” - стеге под Турцима, на трен заборавља. Да је својим континуираним стваралаштвом Николић тако крчио пут и потоњим облицима српске националне књижевности, те утицао на њену рецепцију као и уопште рецепцију драме у позоришту што је њен опет посебан значај, може се назрети и кроз виђење у оно време младог позоришног критичара Светислава Вуловића. Резимирајући утиске о тада већ старинском историјском комаду Атанасија Николића - „Зидање Раванице“ (по народној песми) изведеног 1872. године у Народном позоришту, он износи врло проницљиво мишљење: замера глумцима због лоше глуме и алудира на неодговарајуће костиме и реквизите, међутим додаје да се у ведрој полуопери видело парче старе славе. Да је Вуловић био под утицајем промена начина живота, говори његово запажање и ко за представу мари. Он у својим белешкама истиче да су „не само галерија, него и седишта - чак и првога реда, показивала ћурчета и чакшире“ (Вуловић, 1879:17). Оно што утом стоји непобитно битно, јесте да је ведра „полуопера“ с приказом старе славе очигледно годила пропаћеном српском народу, а будући да је позориште уз књижевне часописе оди- 
Марија Љ. Ивановић

грало врло значајну улогу у формирању шире читалачке и позоришне публике и много допринело националном просвећивању и књижевном образовању ширих слојева народа“" (Историја српског народа, књ. V-2. 1981:396-397), без устезања јој се може прописати и тај чист просветитељски значај.

На крају, говорећи у овом раду о уметничком значају, не најбитнијем, али веома значајаном, кроз осврт на преовлађујућу музику тога времена, такође се може донекле изнети једна од димензија улоге Николићевих драмских остварања. Као дела композитне уметности, његове драме отвориле су нови талас стваралаштва, опијан дахом италијанског романтизма и уопште европске опере. Наиме, до појаве Шлезингера, капел мајстора Књажевско-сербске банде ${ }^{8}$ или „оркестра који је имао задатак да свира на свим државним и црквеним свечаностима, на баловима и парадама, понекад уз хор, турска музика била је обавезан пратилац кнеза у свим приликама“ (Ђурић, 2001:131). Промена тог правца уследила је након Сретењске скупштине 1835. године, а Шлезингерово можда најзначајније дело је комад „Женидба цара Душана“, драма у три чина с певањем, коју је „за распуст, кад не имаше посла са својим предметима“" (Николић, 2002:75) сачинио Атанасије Николић у очи св. Арханђела Михаила. У почаст Књазу за имендан, драма је представљена у великом школском ходнику лицејско-гимназијске зграде 7. новембра 1840. године. Та прва позоришна представа изведена после оних Вујићевих из 1836. године, у којој је главну улогу играо писац сам, (а где је мелодије за песме Николић удесио са капел мајстором Шлезингером), по Шумаревићу, била је нека врста опере. ${ }^{9}$ О представи изведеној на свечаности кнежевог имендана, писале су „Новине Србске“ (број 47, 1840):

8 Капел Мајстор Шлезингер, кнежев учитељ музике (учио је децу Јеврема Обреновића), писао је аранжмане, обрађивао народне песме или изводио своје композиције. „Поред музике за сценска дела, оставио је за собом и велики број маршева, потпурија, хармонизације народних и градских песама писаних за глас и гитару“ (Ђурић, 2001:131-132).

9 Атанасије Николић је у време извођења својих представа у Новом Саду током 30их година XIX века написао и комад „Алписку пастирку“ у коме је било песама, а где Шумаревић наводи да је Николић још тада показао „своје мелодрамске наклоности, које ће у Крагујевцу, са Жениябом ияара Душана развити, готово, до опере. 
Предстиавленије „Женияба иара Душана“ Г. Професором Маиеммаиике у овgашњем Лииеуму Айанасијем Николићем, сочињено је у иесмама на форму йалијански оиера, и заистиа је Г. Николић, како сочиненијем овим, йако и иірањем рола са својим иерсоналом не само сооивейсивовао смислу иредсииавленије, но је свако очекивање како Кюаза, йако и они зрииееља, који су имали иррилике у највећим Евроиејским

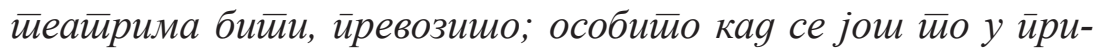
зреније узме, gа ни јеgно оg иірајући лица вежестива у музики нема, а цело иредстиавленије је у ноие сииављено, и зачуgо је свима, gа се нијеgна йоірешка у сойлашавану иеввача са свирачима gоїоgила није. “(..) Оркестиар је сачињавала банgа Кьажеска йоg уиравленијем своїа Кайелмајсииора Јосифа Шлезиніера, који је и све йесме и иіре на нойе сииавио (Шумаревић, 1939:170).

Према српском театрологу Волку, за разлику од претходних, „ова представа је била знатно боље опремљена, рађена је далеко амбициозније и имала је унапред обзнањене циљеве, не само да забави, просвети и културно уздигне публику већ и да створи материјална средства којима би Крагујевачко дилетантско позориште могло да настави још успешније своју активност. Отуд многи историографи позоришта ову представу означавају као зачетак професионалног рада на стварању новог српског позоришта“ (Волк, 1992:24). Такође, званичне похвале Михаила су утом дале подстрек за помоћ и у извесном смислу бригу просветних органа за будуће планове ансамбла. А шта је додатно занимљиво и важно, један од највићих српских комедиографа, Бранислав Нушић, у својој књизи „Стари Београд“, о овом делу које је Николић написао и приредио, говори као о првој српској опери. Он се позива и на речи критичара који је већ након другог играња ове представе 6. децембра на Светог Николу, уместо комада на форму талијански опера исти приказ најозбиљније назвао опером. „У Крагујевцу је тада“, додаје Нушић, „после Вујићевих позоришних представа свет већ био свикао на театар, но ипак је био врло изненађен овим начином приказивања“" (Нушић, 2014:117-118).

Осим за овај комад, Шлезингер је компоновао музику и за Николићевево дело „Краљевић Марко и Арапин“, позоришну игру с пес- 
Марија Љ. Ивановић

мама у три чина, 1841. године; „Зидање Раванице“, позоришну игру у три чина, у стиховима с певањем, написаној према народној (епској) песми, 1846. године; „Песме из трагедије Смрт српскога књаза Михаила Обреновића III“, које је Николић написао након убиства кнеза Михаила кога је изразито ценио.

\section{5. ЗАКЉУЧАК:}

„Народ без народности јесте тело без кости“ (Људевит Гај).

Насупрот једној општој тенденцији ка „универзалној, свељудској култури“ (Кашанин, 1930: [93]), српске историјске драме поседујући „исконску снагу и специфичну естетику народног духа“, помогле су разбуђивање „старог срца јуначког“ те окрепиле српски народ одушевљавајући га за подвиге XIX века. Концепцијом осавремењивања традиције, српске историјске драме које је Атанасије Николић створио транспозицијом српске народне (епске) песме, погодујући потребама и осећањима клонулог српског народа, одржавале су неко време аутентичан израз исте, а да би се све већим продирањем капитализма и технике угасиле, заједно са српским епосом.

Српски романтизам проистекао из просветитељског класицизма, „сав зароњен у историјску прошлост због потребе да се оживи и стабилизује национални дух у народу“ (Ковачек, 2006:273), подстрек је био некдашњем оформљавању првих српских позоришта, која су подизана снагом српских историјскх драма мисионарског, националног и родољубивог значаја. „Национална драма била је и остала основна подлога сваке велике театарске уметности, разлог и смисао њеног постојања, и инспиратор и инспирисани медијум драмске књижевности, оно огледало које је једном друштву и једној средини враћало слику његовог бића и његове егзистенције“ (Финци, 1963:8).

Имајући у виду услове из којих је српска драма поникла - самоникла и углавном спутавана, уместо једностраног вредновања исте компаративнм методом спрам култура које су се развијале под другачијим условима и приликама и чији је народни израз продукт другачијег менталног склопа, перципирана је потреба да се превасходно досеже смисао аутентичности израза као и искушења кроз које је исти (израз) пролазио, како би се потом увидео и сам његов значај. 
Прихватајући и Финцијево виђење по коме „сопствено“ даје „више психолошких могућности извођачима да се целовитије и ефикасније изразе,“ а даје и више моћи да се „непосредније и сугестивније делује на свест и машту публике“(Финци, 1961:10-11), значај српске истријске драме као и народне поезије управо лежи у њеној инспирацији и моћи којом је српски народ успео да доживи културну обнову као и обнову сопствене државности. Народна поезија па српска историјска драма, стварана према властитом искуству, потребама, могућностима и уопште доживљају света, као носилац могућности народног духа, учествовала је у јачању самосвести, али и савести српског народа. Будећи историјску па и метафизичку свест о сопственом идентитету, српске историјске драме - дубоке и свестране, с нарочитом бојом човечнсти, доступности и обилности, традиционалним изразом трајне вредности, носиле су тако предодређени дах...

Без обзира на контроверзе традиције која истовремено може бити „и инспирација и кочница за прави додир са савременошћу“ (Џаџић, 1975: 245), поседујући могућности народног духа - дела традиционалне садржине која делују на стања људи утолико имају и већи значај, што се никада не зна када и у ком облику те „могућности““ могу напрасно да избију, с обзиром да досад нису нити ће икада бити до краја испитне.

\section{ЛИТЕРАТУРА}

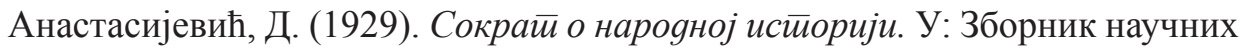
радова Ферди Шишићу: поводом шездесетогодишњице живота 1869 1929. Уредник Грга Новак. Загреб: С. Albrecht.

Барт, Р. (2011). Заяовољсииво у иекксйу. Београд: Службени гласник.

Волк, П. (1992). Позоришни живой у Србији 1835/1944. Београд: ФДУ Институт.

Волк, П. (2009). Преображење: Драма Народног позоришта у Београду од 1868. до 2007. Београд: Алтера.

Вуловић, С. (1879). Из йозоришйа: прве белешке из једне државне и друштвене установе наше. Београд: Државна штампарија.

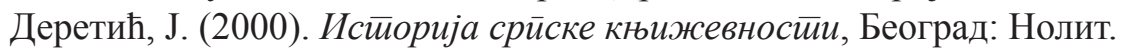


Марија Љ. Ивановић

Ђурић, В. (1958). У: Анйолойјја нарояних ейских иеесама: І. Нови Сад: Матица српска

Ђурић, О. (2001). Воgич кроз истиорију музике. Београд: Војна штампарија.

Јеротић, В. (1998). Дарови наших рођака: психолошки огледи из домаће књижевности. Књига друга. Београд: Просвета.

Игњатовић, Ј. (1874). Србин и юеїова йезија, у: Дјела Јакова Игњатовића. Књ. 1. Нови Сад: Српска државна штампарија.

Исйорија срйскої нароga. Књ. V-2. (1981). Од првог устанка до Берлинског конгреса 1804-1878. Београд: Српска књижевна задруга.

Кашанин, М. (1930). Савремености йраяииије. У: „Препород“ (годишњак): Уредник П. М. Петровић. Београд: Народно дело.

Ковачек, Б. (2006). Талија и Клио I, III: из историје српског позоришта и драме. Нови Сад: Позоришни музеј Војводине.

Лаш, К. (1986). Нариисииччка кулииура. Загреб: ИТРО „Напријед“.

Липовецки, Ж. (1987). Доба иразнине. Нови Сад: Књижевна заједница Новог Сада.

Несторовић, 3. (2016). Велико gоба: Историја развитка драме у српској књижевности XVIII I XIX века. Београд: Клет.

Николић, А. (1841). Краљевић Марко и Арапин:

http://digital.bms.rs/ebiblioteka/pageFlip/reader/index. php?type $=$ publications\&i $\mathrm{d}=2378 \& \mathrm{~m}=2 \#$ page $/ 1 /$ mode $/ 2$ up

Николић, А. (2002). Биоїрафија верно својом руком найисана. Приредили Милоје Р. Сарић, Александар Ж. Петровић. Београд: Српско друштво за историју науке.

Нушић, Б. (2014). Сйари Беоїраg: из полупрошлости. Београд: $3 Д+$.

Павловић Т. (1837). Позоришиеие, нароgь йозоришиее, Србско нароgь йозоришиее. У:Новы сербский льтописъ. Часть друга: Учредникъ Өеодорь Павловичь. Год. ХІ. Кньига 41. У Пешти: Острогонскогъ Кньигопечателя.

Финци, Е. (1961). Више и мағе оg животиа: Утисци из позоришта II. Београд: Просвета.

Финци, Е. (1963). Вище и мање оg животиа. Утисци из позоришта III. Београд: Просвета.

Фрајнд, М. (1986). Павле Пойвић о срйској драми ХІХ века. Београд: Институт за књижевност и уметност.

Фрајнд, М. (1993). Ейски и релиіијски елемениии у іраяњи драмскої сиевва Симе Милуйиновића Сарајлије. У: Сима Милутиновић Сарајлија: књижевно дело и културноисторијска улога: зборник радова са на- 
учног скупа одржаног 15. и 16. октобра 1991. године поводом двестогодишњице песниковог рођења / уредник Марта Фрајнд. Београд: Институт за књижевност и уметност.

Џаџић, П. (1975). Криииика и време. Београд: Просвета.

Штур, Людевит (1857). Кюиїа о народнимъ иесмама и йрийовеgкама славенскимъ. С чешкога превео Јованъ Бошковићъ. Нови Сад: у печатньи Данила Медаковића.

Шумаревић, С. (1938). Читиалишиее. Београд: Штампарија Белетра.

Шумаревић, С. (1939). Позоришиее коg Срба. Београд: Луча.

\title{
Marija Lj. Ivanović
}

\author{
TRANSLATION OF SERBIAN FOLK (EPIC) POETRY \\ INTO SERBIAN HISTORICAL DRAMA: THE AMBIGUITY \\ IN ATANASIJE NIKOLIĆ'S DRAMATIC WORKS
}

\begin{abstract}
Summary
The paper approaches the considerable significance of Serbian historical drama in the literary work of Atanasije Nikolić with regard to the importance of preserving knowledge of folk history and tradition. By the transposition of Serbian folk epic poems into dramas, Nikolić's works, while maintaining the developmental continuity of folk culture - by its authentic expression, modernized the folk tradition and influenced the maintenance and revival of Serbian culture in the 19th century, the century of Uprising. The aim of the paper is to highlight the multifaceted importance of historical drama works, and the general effects on the Serbian people of the time. The problem of relativization of their values is also considered. Under the methodological conception that relies on Schlegel's view of theater according to which it can have a "special charm for all ages, generations and states of people", the expected results indicate how far the folk spirit (embedded in the historical drama) can influence the development of the culture, which seems to us that the deeper it is - the more original, and the more it gains in meaning and significance, with a tendency to become universal, archetypal.
\end{abstract}

Key words: culture, tradition, epos, folk art, "own”, Serbian historical drama, Atanasije Nikolić 